\title{
INSURGENCY IN THE INDIAN NORTHEAST: STUDENT VOICES FROM KOLKATA
}

India's disputed borderland regions consist of Kashmir in the extreme north western part of the subcontinent and the north-east, located on the other side of the subcontinent in the extreme eastern sector of the Himalayas. A disputed territory is an area over which two or more actors (states or ethnic groups) claim sovereignty (Wolff, 2003:3). Since independence in 1947, from British colonial rule, India has had very problematic relations with both Kashmir and the Northeast, both of which have been classified as 'disturbed areas' by the New Delhi political establishment. Both regions have experienced strong secessionist movements that have tried to break away from the Indian union. 'Secession is a bid for independence through the redrawing of a state's geographical boundaries in order to exclude the territory that the seceding group occupies from the state's sovereignty' (Webb, 2012:471). Insurgent groups from both regions, Kashmir and the Indian northeast, do not seem to have a sense of one-ness with the rest of India or India proper. Also, in both regions, external forces have been strongly involved since independence e.g. Pakistan in Kashmir and China and Burma in the Indian north-eastern states. Out of the two disputed borderland regions, this paper will be focussing only on the Indian northeast.

It is the aim of this paper to look into the many facets of the conflict in the Indian northeast and to especially focus on student voices. One reason why students have been chosen for purposes of this paper is because throughout the contemporary history of the Indian northeast especially with regard to Assam, students have been very active in putting their demands forward to the national Indian government and have been active in organising protest movements and causing political agitation. Universities are often the starting points of a revolution, a nationalist movement, political protests etc. This is because education creates a sense of awareness and it is from this sense of awareness that the more educated people in any society begin to question different forms of oppression and injustices. Before the outbreak of the actual political protest, there has often been an intellectual revolt at an earlier phase paving the way for the revolution. This has happened throughout history and we see the same thing happening in different parts of the world. The northeast is no exception, where the All Assam Students Union has played a major role in the protest movements and insurgency of the Indian northeast. Thus, the data that was collected for purposes of this paper has been extracted from students of north eastern origin who had come to study in the city of Kolkata. Although the city of Kolkata is not located in the northeast, it is most certainly the gateway to the Indian Northeast, and is also the nearest biggest city to the northeast where many students of north eastern descent come for jobs and education.

Building on earlier research, the paper argues that several factors have collectively intensified the crisis in the northeast. This includes political instability, kidnappings, inefficiency of the Indian armed forces who fail to maintain law and order, migration from neighbouring Bangladesh, racism, poverty, corruption, environmental factors, social exclusion and economic marginalisation, and human rights abuses caused by both militants and Indian security personnel stationed in the region. India has treated the region and people of north eastern origin as the Indian other', which has to a large extent contributed to the on-going conflicts and the secessionist movements in the northeast. It is a common experience for a person from the northeast to be recognised as a foreigner by people living in India proper (Wouters and Subba, 2013:127). 'The racial 
distinctiveness of the Northeast maintains a gap-at once racial, geographic, cultural, spiritual and moral- between the Northeast and the rest of the country' (McDuie-Ra, 2015:305). Racism directed at people of north eastern descent often 'brings them into solidarity with one another, especially while outside their homelands in metropolitan cities of India' (McDuie-Ra, 2016:405). This 'othering', becomes clear when we look at New Delhi's policies directed towards the northeast from the 50's till the present day. An example of India's policy towards the borderland region includes the Armed Forces Special Powers Act, which gives security personnel from India proper extraordinary powers to deal with these 'disturbed areas'. The Act has paved the way for all sorts of human rights violations to take place, caused primarily by the Indian Army and para military troops. Such draconian acts have to a large extent been responsible for the violence in the region, since a lot of the political violence in the region is a protest against the repressive AFSPA. The attempt to exploit regional north eastern resources by New Delhi for the needs of people living in India proper, and the involvement of external powers like China, Bangladesh and Myanmar in these conflicts have further problematized the already complicated situation. It is not possible to focus on all the factors mentioned above in great detail in this paper. All the factors mentioned above have been touched upon throughout the course of the paper but there is an emphasis on the issue of corruption and the Armed Forces Special Powers Act. Finally, the paper shows that levels of violence differ from one part of the northeast to another and through the data it becomes clear that Manipur has been the most troubled part of the Indian north east in recent times.

\section{BACKGROUND TO THE INDIAN NORTHEAST:}

Geographically, the Indian northeast, is tucked away in the extreme north eastern part of southern Asia, and is believed to thrive by itself. The Indian northeast has international boundaries with Bangladesh, Bhutan, China and Myanmar. The northeast is a sensitive area which has struggled with the dominance of the centre, and has also struggled with issues of identity and ethnicity within the region (Ghose, 1998:146). North east India is one of southern Asia's 'most contested spaces' (McDuie-Ra, 2009:255). The 'northeast' is sometimes seen as a region in itself, cut off from the Indian mainstream, and the geographical and political isolation of the northeast only serves to reinforce this image of the northeast being a separate region (Farelly, 2009:284). The northeast has often been imagined in opposition to the Indian mainland, the mainstream, the Indian centre or the Indian core (Ibid). This is a part of India which is isolated and connected to India proper only by a small strip of land often called the 'chicken's neck' or the Siliguri corridor. The geographical isolation of the region, absence of cultural and psychological integration with the mainstream and economic discontent are the root causes of the unrest and instability in the Northeast' (Dutta, 2000:2123). The marginalisation of this part of India in the national consciousness of India often gets reflected in the dominant media content (Sonwalkar, 2004:395). For instance, Doordarshan, the state owned television network, has never had a person of north eastern descent on its national channel and a similar situation exists with regard to other private channels such as Zee, Sony, Star and Aaj Tak (Ibid). Levels of violence in this part of India's borderland regions arise from strong feelings of exclusion, socio economic marginalisation and alienation. However, it has been suggested by some specialists that this feeling of isolation might come to an end in the years to come with India's 'Look East Policy' (Haokip, 2012:390). The region is somewhat sandwiched in between India proper or South Asia proper and East Asia, and hence the cultural values of the people of this part of India/Asia seems to be a syncretic fusion of South Asian values and East Asian values. For instance, some of the 
Hindu temples in the region resemble and are easily mistaken for Chinese style pagodas. ${ }^{1}$ When one takes a look at an individual from this remote part of India, the individual is easily mistaken for being Chinese or East Asian. Many Indonesian tribes have a lot in common with the Naga communities of north eastern India (Glancey, 2011:74). Naga thatched homes are very similar to those found in Borneo and Indonesia (Ibid, 76). The north east region of India is thus often dismissed as the mongoloid fringe of India, which consists of the seven sister states namely: Assam, Manipur, Nagaland, Tripura, Arunachal Pradesh, Mizoram and Meghalaya. Now of course, Sikkim has been added to the list. Many of the states in the region like Nagaland were actually carved out from Assam (Haokip, 2012:304), which has a central and dominant position in the region, and this was done to try and resolve some of the on-going ethnic tension. Geographically, the region is hilly and has a very difficult terrain, similar to Kashmir. The region's current geopolitical reality is a legacy of the colonial administration that separated hills and plains, and the partition of British Burma from British India (McDuie-Ra, 2009:314).

Here, in the Indian northeast the conflict is indeed very complex, and exists at many different levels. 'India's north-eastern frontier is one of South Asia's hottest trouble spots' (Hussain, 2007:93). The region is an ethnic minefield. 'A cursory look at the demographic mosaic of north eastern India would show that this region is home to a curious amalgam of cross cutting societies' (Dutta, 2000:1495). The region is very diverse racially, and is culturally heterogeneous. The region has always had complicated relations with New Delhi and with the rest of India. However, the conflict is not just between the region as a whole and with the rest of India. Because the region itself is so diverse, there are on-going conflicts between different states within the region, e.g. Nagaland and Manipur do not have very friendly relations with each other. So the conflict is also between different states in the region. There is also a great deal of hostility between those who see themselves as 'insiders', and those who are perceived as 'outsiders. There is a great deal of hostility between different tribal groups and also between tribal people and non-tribal people. The problem over here has been linked with self-determination and the effort to achieve political independence or at least more autonomy from India. Some of the problems have also revolved around identity and land ownership (Haokip, 2013:79). The issue is not just over sovereignty but also over unregulated migration. The Northeast has been at the receiving end of a variety of immigrants, each with a distinct identity (Rao, 2009:208). 'Rife with the politics of sub nationalism and movements for local independence, the region has so many insurgent outfits of different hues that a separation between insurgency and mainstream social and political life there cannot be made' (Sabhlok, 2009:505). The Indian north-east has always been in the news for negative reasons, some of which include agitation, political violence, human rights abuses and corruption (Dutta, 2001:73). Poverty and poor governance is also most certainly part of the problem. In addition to poverty, other problems include poor urban planning, pollution, and environmental problems (Hazarika, 2008:75).

The conflict in Nagaland has been the oldest. It has been argued that Nagaland has actively encouraged all other ethnic groups in the Indian north east to demand separatism from New Delhi or for separate statehood within India (Prasad and Sinha, 2012:186). Elements from the Naga community have declared that they are Indians not by choice but by force, and that they were brought into the Indian union or Indian mainstream through British conquests. They have argued that now that the British have left, they should revert back to their previous situation of

\footnotetext{
${ }^{1}$ Participant Observation, Research Fieldtrip to the Indian Northeast, Jan, 2014.
} 
independence. The main political force that has been active in this regard is the NSCN/National Socialist Council of Nagaland. The NSCN is essentially a Marxist revolutionary Christian force that wants to bring all Naga people living in the Indian northeast and Myanmar together as one administrative/political unit. This aim/ideology of the NSCN is called 'Nagalim' or 'Greater Nagaland'. If the political ideology of 'Nagalim' or greater Nagaland were to become a reality, it would be a Christian country, and also the first proposed Christian country in south Asia (Mall, 2012:137). The early nineties has seen a rise in political violence and militancy as security forces have 'stepped up operations against both the factions of the NSCN (NSCN/K and NSCN/IM)' (Singh, 2007:816). A similar group in neighbouring Assam is the ULFA/United Liberation Front of Assam. The NSCN/IM's political aim is Naga territorial unification and sovereignty based on the 'historical narrative of Naga independence before British rule in the late $19^{\text {th }}$ century' (Goswami, 2010:97). The NSCN/K aims to 'create an independent sovereign Christian Socialist Republic through the principle of people's supremacy, comprising all Naga inhabited areas in Nagaland, and especially those in Myanmar' (Ibid, 98). Since 1955, Nagaland has remained as one of the most militarised regions of the world, and the brutality directed at the people from the side of the Indian government has been high (Thong, 2010:597). Even today the situation remains critical. People are being mysteriously killed. The Assam chief minister, Tarun Gogoi, recently said, he wanted a CBI inquiry into the killing of nine individuals, 'whose decomposed bodies were found in Dimapur, Nagaland, neighbouring Assam's Karbi Anglong district' (The Telegraph, 2014:6).

A crucial moment in Naga history in terms of the state's relations with the rest of India was $29^{\text {th }}$ June, 1947, when Akbar Hydari, the then Governor of Assam promulgated the nine point declaration (Bajpai, 2002:66). In those days the Naga areas were a part of Assam. Bajpai writes that 'the declaration included agreements on judicial processes based on Naga customary law, legislation based on Naga consent, Naga lands for Nagas, tax collection by the NNC/Naga National Council, bringing all Nagas under one administrative unit as well as recovery of forests that had been transferred to other parts of Assam, the continuation of Inner Line regulations, and so on' (Bajpai, 2002: 66). Most important though was the ninth clause which stated that while India would have special responsibility for the Naga areas for ten years, at the end of the period the NNC will be asked whether they require this agreement to be extended for a further period or should a new agreement be arrived at concerning the future of Naga people.

In Assam, the Bodo community want to carve out a Bodo land for themselves. 'In the mid 80 's, the Bodos, the largest plain tribe of Assam, began a vigorous agitation for the creation of a separate Bodoland state along the north banks of the Brahmaputra' (Singh, 2008:1104). Bodos have fought with non Bodo communities. Hindu Assamese have been in conflict with Hindu Bengali's. Sanjib Baruah argues that the 'unresolved tensions between regional patriotism and pan Indianism explains the insurgent organisation's resilience and continuing appeal of its political ideology' (Baruah, 2009:951). The north eastern states have argued that the infiltration of Bangladeshi migrants into the region is increasingly undermining and diluting the mongoloid ethos of the Indian north east. The Nagas of Nagaland, for instance, belong to the Tibeto-Burman language family (Joshi, 2007:542). The Indian government has not done very much to control the continuous waves of migration from Bangladesh into India, which has been a contentious issue especially with regard to the Indian northeast. One of the most powerful student bodies in Assam that felt very strongly about regional political matters was the All Assam Students Union, and this body had started a movement against 'illegal migrants' (Hazarika, 2000:64). It should be noted though that migrants were not 
coming only from Bangladesh, but also from other parts of the subcontinent like Nepal, and the Indian states of West Bengal and Bihar (Hazarika, 2011:31).

Unlike Kashmir, the conflict here in the Indian northeast, as many locals would say, has less of an external dimension. That said, the NSCN/IM has been heavily dependent on external support and is suspected of having strong connections with the Kachin Independence Organisation and the Karen National Union in Myanmar (Goswami, 2010:114). One could, of course, at least say that the external dimension with regard to the Indian northeast is not as pronounced as the situation in Indian Kashmir. China and Burma have meddled in the conflict on earlier occasions, but today the conflict has more of an internal dimension and is more internal to India. In Kashmir, however, Pakistani Islamist militants are still believed to play a major role in the Kashmir conflict. The revolutionary force in Assam is the ULFA/United Liberation Front of Assam, which was formed in 1979. It has the aim of liberating the state of Assam, from the Indian colonial regime, through armed struggle, and to bring about a radical transformation of Assamese society through scientific socialism (Singh, 2001:154). Although, the conflict in the Indian northeast is primarily seen as an internal problem, it is worth noting that the ULFA has set up bases in neighbouring Bangladesh and also in the western forests of Burma, where the Indian authorities are not likely to have much control (Myint-U, 2011:289). In Myanmar's Sagaing region, officials have said recently, KLO/Kamtapur Liberation Organisation cadres 'share camps with Naga and Meitei insurgent groups. The region is a hotbed of militants who operate across the border in Nagaland, Arunachal Pradesh, Manipur and beyond in Assam and Bengal. Their weapons are procured mostly from China' (Dholabhai, 2014:7).

Another area of conflict in the north eastern region is Manipur. 'With its hill and valley divide, scheduled tribe and non-scheduled tribe conflict, corrupt politics, absence of governance, indifferent administration, and ever increasing fractures in society along ethnic lines, Manipuri society has become the breeding ground for ethnic insurgent groups' (Singh, 2008:1117). The hill areas are inhabited by the Naga communities, and the Kuki and Zoumi surround the fertile valleys which are occupied by the Meitei (Nanavatty, 2013:42). The struggle is over land ownership and land for cultivation. In the struggle for a Kuki homeland, and Greater Nagaland, Kuki tribes and Naga's now claim the same geographical areas in four hill districts of Manipur which include Chandel, Ukhrul, Senapati and Tamenglong, as their own territories (Kipgen, 2013:34). These competing demands have escalated the levels of violence and militancy in the region. What has exacerbated the situation of course is the government's unequal treatment and discriminatory attitude towards the Kukis. Whilst the Meiteis have opposed the creation of a Kuki homeland, or for that matter a greater Nagaland, the Kuki and Naga communities are highly fragmented and are unable to establish friendly relations with one another. The problem was not just between different ethnic groups in Manipur, but the Meiteis had also challenged the legal and political validity of the merger between India and the kingdom of Manipur (Haksar, 2013:157). So the problem has also been between the individual state of Manipur and the centre/New Delhi as well.

Manipur is also a region that has been subjected to the Armed Forces Special Powers Act. As a result of the act, there have been gross human rights violations in the region. Human rights activists like Irom Sharmila and Bina Lakshmi Nepram have protested against the Armed Forces Special Powers Act. Irom Sharmila has been on hunger strike as a result of the political situation. She has been on hunger strike for a while now and is protesting against the AFSPA. Nepram has argued that as a result of the AFSPA, the Indian Army have killed so many men, that now women are having 
to leave their homes and fight against the mighty Indian state and stand up against India's oppression. Nepram argues that women have lost their fathers, brothers and sons as a result of the constant shooting and firing in the region which has happened as a result of the AFSPA, and thus women have been forced to come forward to take action. She firmly believes that only women can bring about effective change and peace in Manipur. Nepram also believes in the empowerment of women and her organisation has opened bank accounts for women and made arrangements for interest free loans for women who are struggling in these conflict zones in the Indian northeast. She argues that women have responded in three ways to the situation in Manipur: firstly women act as survivors, then as protesters, and finally the more educated women raise awareness both nationally and internationally about the problem in Manipur, which needs and deserves urgent attention from both New Delhi and from the international community. Her movement is a peaceful one, has been hugely influential and in this connection, mention maybe made of the Manipur Women's Gun Survivors Network ${ }^{2}$. Thus, there is a strong gendered dimension to the conflict here in Manipur, which we don't see in places like Kashmir. On the contrary, Kashmir is apparently a male region. With Kashmir being a predominantly Muslim region, it is hard to see local Kashmiri women out on the streets because of Islamic sexual segregation. ${ }^{3}$ Muslim women in Kashmir are mainly confined to the domestic household, whereas in Manipur, women are easily visible on the streets, protesting against the representatives of the Indian state.

\section{THE ISSUE OF CORRUPTION IN THE NORTHEAST:}

Corruption has been one of the biggest challenges in the Indian northeast. This is also something that many of my interviewees mentioned when I carried out the research for this paper. The practise of looting the state was fairly straightforward. Whenever any commodity was being supplied e.g. bricks, cement, medicines, hospital equipment, rice or sugar, they were often overinvoiced. For instance, if 100 quantity of an item was supplied, the bill for that would not be shown as 100 , but as 1000 of the quantity. The charge taken report would also show the quantity as 1000 . This seemed to be the standard practise (Rammohan, 2014:86-89). Again, if a $100 \mathrm{~km}$ road was to be built, very often the materials supplied would be shown for $1000 \mathrm{~km}$. On some occasions no roads would even be built, but it would be shown in the books as built (Ibid). Thus, in the northeast, hundreds of roads have been built on paper but not in reality or actual fact. Often, the indigenous regional political parties would be involved in such cases. With regard to corruption, out of all the states $^{4}$ in the northeast, Manipur seems to be on top of the list. Rice, wheat and sugar are regularly downloaded at rail heads in places like Dimapur, Tinsukia, Gawhati and Bongaigaon, and then these have often been diverted to the black market. There has been considerable corruption within the Nagaland government. 'One result has been frequent late payments to government employees and a consistent need for governmental borrowing (Cline, 2006:132). Another area of political corruption in Nagaland relates to the electoral system. Vote rigging and electoral fraud are common practise in this part of India (Ibid). The governing structure that has been put in place in the region is secured with a heavy presence of armed forces and security personnel (Vandenhelsken and Karlsson, 2016:331). This obviously does not help the already strained situation. The region is often described as backward, lacking basic infrastructure, hard to govern and infested with tribal militias (Ibid).

\footnotetext{
${ }^{2}$ http://womengunsurvivorsnetwork.org (Accessed, 28.03.2014).

3 Participant Observation, Fieldtrip to Kashmir, Dec, 2012, and Dec, 2013.

${ }^{4}$ The term, 'state' in the Indian context refers to administrative-political unit.
} 


\section{THE ARMED FORCES SPECIAL POWERS ACT:}

The Armed Forces Special Powers Act came into existence in the year 1958, in postindependence India, but was based on a British colonial law, the British Armed Forces Special Ordinance (Kikon, 2009:275). The British law was passed in pre independence India in the year 1942, when Indian nationalism was at its height and the colonial authorities had to give special powers to security personnel to deal with the on-going tensions, in other words to crush the rising tide of Indian nationalism. Initially, the act was meant to operate for one year. It does not apply uniformly to the north east region. It applies primarily to areas which are classified as 'disturbed' by the Indian government. There is some recognition from the side of the political elite in New Delhi that the levels of violence and militancy differ from place to place within the region, and hence it does not apply uniformly throughout the northeast. For instance, states like Mizoram and Sikkim are seen as peaceful and hence they are not classified as 'disturbed'. However, the act applies to the whole state of Assam, Manipur and Nagaland, which hints at the fact that the levels of insurgency in these parts of the northeast are at its peak. This label of whether or not a state is disturbed is decided by the Ministry of Home Affairs (McDuie-Ra, 2009:258). Labelling a state as 'disturbed' previously had no limit but since the late 1990's, there have been huge protests by groups such as the Naga People's Movement for Human Rights, and hence the label of whether or not a state is 'disturbed' must be reviewed periodically (Ibid). Thus, the label must be reviewed at an interval of six months, and yet there is no limit on the number of times this label can be renewed. This means that some places can be and have been classified as 'disturbed' for decades. The act gives security personnel extraordinary power to deal with these so called disturbed states of India. Security personnel from mainstream India have often abused and misused their power which has paved the way for all sort of human rights violations to take place. Sudhir Chandra writes, 'The Armed Forces Special Powers Act, a measure that virtually denies people in the affected areas access to legal redress and grants the armed forces near total impunity, is an ominous illustration of the pervasive perversion of the democratic ethos, not just the democratic process, in India (Chandra, 2007:49). The act is not subject to judicial review, and neither can it be contested by civil society actors or by local governments. It is strongly associated with arbitrary killings, torture, brutality and inhuman treatment of local people. The act is ineffective and has been counter-productive. A lot of the protest and violence in the northeast is because of this repressive act, and yet those who are in favour of the act argue that the militancy is proof as to why the act should be enforced in the region. The advocates argue that so long the northeast is in a situation of emergency, the act should be enforced in the region, and yet it is questionable who is actually causing the violence: the militants or the Indian state?

\section{STUDENT VOICES FROM KOLKATA:}

I was able to gather some data after a recent fieldtrip to India. All my interviewee's were ethnically of north eastern origin, and from different parts of the Indian northeast. Many of these north eastern people come to the Scottish Church College of Kolkata to study, which is where I carried out most of the interviews. The college, which comes under the University of Calcutta, is one of the few colleges in India, which have a large number of their seats reserved for people of north eastern origin. Kolkata is a major city in eastern India, the capital of West Bengal, and is a fast developing metropolis, which is often seen as the gateway to the Indian northeast. When I got the opportunity to carry out these interviews in Kolkata with these people from the north east, this is what they had to say: 
My first interviewee mentioned that Manipur was very corrupt. There is a great deal of terrorism going on there ${ }^{5}$. He also hinted at the high levels of corruption. He mentioned, even after one clears ones exams, it is difficult to get jobs and one has to pay government officials to get into the civil service. Nagaland managed to get government funding from the centre, but a large part of these government funds which were supposed to be used for infrastructure development, went into the pockets of local politicians in the north east. He went on to say that Gawhati, which is one of the main cities of Assam, is probably the only city which can be considered as fast developing, unlike the other cities in the region. There are military commanders especially men associated with the Border Security Force and the Central Reserve Police Force, who are constantly patrolling the region. There is a strong presence of the military and para military forces especially in Manipur, and the situation is quite scary at night. If there is a rally or a public protest (against the on-going injustices and oppression) by the local people, the security forces often fire into the sky to scare the local people or protesters away and to disperse the crowd. For instance, a lot of firing took place in an area called Churachandpur, Manipur. Despite police brutality, this interviewee maintained that the presence of security personnel has helped to some extent. The problem in the region is often caused by 'underground elements'. But after these 'underground elements' are caught, and once they surrender themselves to the security forces, they are actually given jobs. The Khuga dam area in Manipur is a heavily militarised region and most of the security personnel stationed there are ex terrorists. The same interviewee also mentioned how marginalised north eastern people felt when they were in India proper. He mentioned about Nido, the young man from Arunachal Pradesh who was beaten to death in New Delhi in early 2014. After this incident, there were many protests all over India. People of north eastern origin in places like Safdarjung in New Delhi have been asked to move out. Finally, my interviewee spoke about the racism that they were all subjected to in India proper. He said mainstream Indians often call us 'Chinki' which is an offensive term to usesomewhat similar to the word 'Paki' in Great Britain, which is often used by racists for people of South Asian descent. He ended on a slightly more positive note, saying that not everybody was racist. The people of Kolkata, he mentioned, were quite friendly.

My second interviewee mentioned that the economy in Manipur was very poor, and that there were constant strikes or 'bandhs'. ${ }^{6}$

My third interviewee ${ }^{7}$ mentioned that the economic situation in most parts of the north east was bad. He spoke about the Mizo National Front, a political party, which had tried fighting for independence from India in the 1960s, but the central government had successfully crushed the movement. The plans and aims of the Mizo National Front were not fully known. The Mizo people and the Naga people from Nagaland share the same faith: Christianity. The same interviewee mentioned that the insurgency in the Indian north east is still active, although it may not be a big threat. In Nagaland, the NSCN, National Socialist Council of Nagaland is one of the main insurgent groups. There are also pro- independence groups operating from across the border, from places like China and Myanmar. However, most Naga people, he mentioned wanted to be a part of India. The same interviewee mentioned about racism and how mainstream Indians would make fun of people of north east origin. However, he also mentioned that the Delhi Police were looking into this. There

\footnotetext{
${ }^{5}$ Interview carried out in Kolkata, India, $4^{\text {th }}$ July, 2014.

${ }^{6}$ Interview carried out in Kolkata, India, $4^{\text {th }}$ July, 2014.

${ }^{7}$ Interview carried out in Kolkata, India, $4^{\text {th }}$ July, 2014.
} 
was a special branch of the Delhi Police that looked after the north eastern region, so if people had any complains, they could go to this particular branch of the Delhi Police to get their voices heard. The Armed Forces Special Powers Act still exists, and applies to places like Manipur and Kashmir. The Act is unjust and is similar to the Rowlatt Act during the times of British rule in India. This right gives the army the power to shoot an individual if he is suspected to be a terrorist. Irom Sharmila has protested against this act and has been on hunger strike for a while now, as a part of the protest. In this context of the Armed Forces Special Powers Act, my interviewee spoke about the Assam Rifles, which is a branch of the Indian para military forces that consisted of a mixed group of people from different parts of India. Sometimes, the jawans or military personnel rape women. Moving away from the politics of the region, the same interviewee mentioned about the other factors like the environmental factors which had complicated the situation further. During the monsoons for instance, buildings often collapse, and there are frequent landslides. There are also major problems with water and water scarcity. Moving away from the general scene of the north east, he chose to speak more specifically about the situation in Manipur. In Manipur, there are different tribes and races, the largest one being the Meitei. Others include the Hmar, Kuki, Thado, the Naga's and so on. Different groups have different motives. They may have the mind set of terrorists or they may not. This has led to much violence in Manipur. The Kuki's want another state. They call this state Kukiland, similar to the Telengana region in South India. Thado tribes want more autonomy. The Naga people living in Manipur want to move out of Manipur. Most Naga people live on the borders between Nagaland and Manipur. My interviewee strongly believed that the cause of problems in Manipur was due to the presence of too many different tribes who wanted different things, which were often in conflict with each other. There were too many different mind-sets. Moving away from the situation in Manipur, my interviewee spoke a bit about neighbouring Mizoram. Mizoram is a peaceful state, in contrast to Manipur. The National Democratic Alliance gave a peace bonus to Mizoram during the time of Atal Biharee Bajpai. There is no army duty in Mizoram. The peace comes from the strong presence of Christianity in Mizoram. Finally, the same man spoke a bit about the situation in Nagaland. The NSCN, he maintained was a minority, and they do not really have a loud voice. Muivah, the leader of Naga nationalism, has tried to free the Naga people from India. Twenty to thirty years from now, the NSCN will disappear. They are already a minority, and very small numbers of Naga people have faith in them and their aims. Muivah, does not have many followers, and when he dies, the NSCN movement will fizzle out. He ended by saying, feelings of isolation and alienation are still very high amongst people of the North East.

My fourth interviewee mentioned that there are different ethnic tribes in Manipur. Some are fighting for better lives, and the political equilibrium changes from time to time. ${ }^{8}$ Many are demanding for a better economic status. Each state within the north eastern region has a distinct political situation. The political situation differs from place to place within the region. The presence of security forces is very much necessary. When there is turmoil in the region, which the regional government cannot control, help from the central government is required. Even now the situation is problematic in places like Assam and Manipur. Underground elements want better political status. They make their demands to both the regional government as well as to the central government. The rebel groups themselves are also very much divided.

\footnotetext{
${ }^{8}$ Interview carried out in Kolkata, India, $4^{\text {th }}$ July, 2014.
} 
My fifth interviewee mentioned that the situation in Tripura was unstable. There have been riots in recent times. ${ }^{9}$ Levels of corruption are very high, and political leaders provide money to villagers so that they can win votes. Political leaders give them money, but the voters or villagers are not sure of what the results will be. Terrorism existed a few years ago, but today the situation seems to be a lot better. There was tension between different ethnic groups. He mentioned that the Chakma's did not get citizenship in Arunachal Pradesh. The $13^{\text {th }}$ hearing is going on at the High Court in Gawhati, and the granting of citizenship is expected this year or next year. Chakma's currently have no state, and the Mizo's are controlling the Chakma's. There are NGO's working for Chakma rights, but the Chakma's still don't have full rights and are not very educated. The origin of the Chakma's is in Bangladesh, and they mainly practise Buddhism. There is some tension between the Mizo people and the Chakma's.

My sixth interviewee mentioned that insurgent groups like the NSCN are operating and active in two districts of Arunachal Pradesh: Tirap and Changlang ${ }^{10}$. The other districts of Arunachal Pradesh are however, peaceful. This interviewee mentioned during his stay in Manipur from 2003 till 2010 , he had witnessed militancy in the form of bombing, explosives and grenades. The situation in Manipur was tensed. By comparison, Arunachal Pradesh was peaceful.

My seventh interviewee interestingly spoke to me about the situation in Meghalaya, (which is generally considered to be a peaceful state in the north east like Mizoram), but he had a different story to tell. ${ }^{11}$ He started by saying that the situation in Meghalaya was politically unstable. The law and order situation is fast deteriorating. He spoke about the rise of insurgency in the Garo Hills of Meghalaya. He mentioned that the centre, New Delhi, was not interested in peace talks but was only interested in taking action against the insurgency. The problem is still very much on-going. Politicians in the region are corrupt, and the insurgents in Meghalaya maintain strong connections with other insurgent groups from other Indian states like the United Liberation Front of Assam and the National Socialist Council of Nagaland and also with groups in Bangladesh. The Garo National Liberation Army is currently causing trouble in Meghalaya. Generally one would regard Meghalaya as a peaceful state, but the insurgents cause problems, especially in the more remote areas. Their main aim is to carve out a separate state called Garoland. The three main communities in Meghalaya are the Khasi, the Garo and the Jaintya. There is tension between these communities, and many want a separate government. Kidnapping, extortion and killing are regular occurrences. The capital city, Shillong, is comparatively peaceful. Most governments cannot finish the full five year term, and they do not last for very long. Governments in the north east tend to break up after 2-2.5 years, and corruption is entrenched. When it comes to the general economic situation and infrastructure, Meghalaya is better off than places Nagaland and Manipur. He ended by saying, although there is a strong presence of the police especially the Central Reserve Police Force, one hardly gets to hear of insurgents being arrested.

\footnotetext{
${ }^{9}$ Interview carried out in Kolkata, India, $4^{\text {th }}$ July, 2014.

${ }^{10}$ Interview carried out in Kolkata, India, $4^{\text {th }}$ July, 2014.

${ }^{11}$ Interview carried out in Kolkata, India, $4^{\text {th }}$ July, 2014.
} 
My eighth interviewee was a Naga man who mentioned that the situation in Nagaland is currently peaceful and that although he looked different from mainstream Indians, he still felt a sense of one ness with India. ${ }^{12}$

My ninth interviewee mentioned that insurgents don't feel 'Indian'. They don't feel that they are a part of India. ${ }^{13}$ They feel that they should have their own government. The insurgency is still active but only in places like the outskirts of Manipur. He mentioned that the 'underground' elements hated the Indian military. This is because the underground elements want their own country, but the military was stopping them.

My tenth interviewee was from Jalpaiguri in North Bengal, which is close to Bodoland in Assam. This interviewee was a Bodo himself. He mentioned that due to the problems in Bodoland in Assam, he and his family were forced to move out of Assam to North Benga ${ }^{14}$. Bodo's have been struggling to get their own land, which they call Bodoland, but they have not been very successful. Generally, Muslims and people of other racial/religious backgrounds tend to feel very marginalised in the villages which tend to have a dominant Bodo presence, and often they leave. My interviewee maintained that although Assam had achieved a certain degree of normalcy, the situation was still quite dangerous. Bodo people feel that they have a distinct culture which needs to be preserved and they want to rule the land themselves. They want to have their own government. Some of the members of the United Liberation Front of Assam are Bodo's. The situation now of course is a lot better. Currently, the ULFA is silent, but they can be active at any time. The ULFA has been working for Bodoland.

My eleventh interviewee was also a Bodo man. He was from Alipur Duar in North Bengal, which again is also close to Bodoland in Assam. He mentioned that the main point in the conflict was with Bangladeshi Muslims, particularly over the question of land ownership. ${ }^{15}$ Before the arrival of Bangladeshi people, land belonged to the Bodo's. Most Bodo people are farmers, so they obviously need the land. But after the arrival of Bangladeshi people into the region, Bangladeshi's also want rights over land, and this has only added more fuel to the conflict. The problem has not been fully resolved yet. It is a work in progress.

My twelfth and final interviewee was a young man from Mizoram. He started by saying that excepting Mizoram, there was insurgency throughout the north east and that many of these insurgents actually had influence over the regional governments especially in Manipur. ${ }^{16}$ The border regions of Assam are particularly dangerous, especially villages like Kalain. The border regions of Assam with other neighbouring north eastern states is a hotbed of insurgency in the sense that people are robbed on a regular basis, and vehicles are stopped and searched by the insurgents. On one occasion, whilst my interviewee was travelling in the region by car, the insurgents stopped the car by placing a massive piece of wood on the road to prevent the car from going any further. My interviewee and the other passengers were searched and robbed. My interviewee mentioned if the passengers did not give up their valuables, then all sorts of atrocities would begin to take place. He

\footnotetext{
12 Interview carried out in Kolkata, India, $9^{\text {th }}$ July, 2014.

${ }^{13}$ Interview carried out in Kolkata, India, $16^{\text {th }}$ July, 2014.

${ }^{14}$ Interview carried out in Kolkata, India, 17 ${ }^{\text {th }}$ July, 2014.

${ }^{15}$ Interview carried out in Kolkata, India, 17 ${ }^{\text {th }}$ July, 2014.

${ }^{16}$ Interview carried out in Kolkata, India, 22 ${ }^{\text {nd }}$ July, 2014.
} 
said that although the government of Mizoram was trying to protect people and passengers, they did not have control over the areas which fell out of the Mizo border. The Assamese government did not pay much attention to these issues of security in the borders. This incident happened to my interviewee in the month of December, in 2011. Land transport had become a major problem in the north east because of the insurgency. With regard to Mizoram in particular, my interviewee spoke about the problems between the Bru refugees from Bangladesh and the local Mizo people. The Bru people occupy parts of Mizoram, and have demanded for an autonomous region. They have been accepted as citizens of India and also as Mizo. If the Bru people follow the Mizo government and its rules and if they abide by the law, they will then be entitled to certain facilities like rice, safe drinking water etc. Many have accepted these terms and conditions offered by the Mizo government, but some have also refused to accept the offer. Some amongst the Bru people have been known to kidnap Mizo people, keeping them in the forests, and then demanding money from the Mizo government. This problem has been going on for a while and still has not been fully resolved.

\section{CONCLUSION:}

In conclusion, it could be said that there are still feelings of separatism in India's borderland regions, but to what extent these feelings constitute a real threat to India, is debatable. From most of the interview material gathered in this paper, it seems clear that the insurgents are a minority, and will not be a major challenge to India in the years to come, unless there is external help from other countries like China, Bangladesh and Myanmar. The same probably applies to India's other disputed borderlands like Kashmir. Because the infiltration of foreigners and militants is a problem, border patrolling needs to be tightened. This will obviously be a very challenging task for India since the region is mountainous. Since corruption is part of the problem, border officials and security forces need to be paid higher salaries, so that they do not accept bribes from people who want to cross over into India from the other side. The market town of Moreh in Manipur is a place where people can easily cross the border and come into India from Myanmar after paying the border security officials some money. ${ }^{17}$ This is most certainly a matter of concern for India. Obviously if people coming from Myanmar are sympathetic to the needs and aspirations of the insurgents, then the insurgency is likely to gain in strength. Many of these ethnic groups in the northeast share a sense of one ness with people living in northern Burma being of the same racial descent. They also often practise the same religion: Christianity. Analysts have often debated to what extent is Christianity strengthening the separatist tendencies in the Indian northeast.

Apart from strict border patrolling, other issues which need urgent attention include issues of infrastructure development, governance, and corruption. The northeast lacks basic infrastructure and is vulnerable to environmental disasters, as one of my interviewee's mentioned. The recent earthquake in Myanmar, April, 2016, had shaken several parts of the Indian northeast including Assam and Arunachal Pradesh. Although India has experienced impressive economic growth rates in recent years, the trickledown effect of this growth rate has not really reached the borderlands. The Indian northeast is totally impoverished. Power cuts are common, and public buildings often do not have running water. Democracy is not just about political democracy and free and fair elections, but it is also about economic and social democracy. The people of these regions often lack access to basic health care, education, transportation and other facilities which people living in India proper

${ }^{17}$ Interviews carried out in Imphal, Manipur, 2012, 2013, 2014 and 2015. 
enjoy. Being the world's largest democracy, it is important for New Delhi to look into this and make sure that people have access to the basic necessities of life. With regard to infrastructure development, it is not just about developing the regional infrastructure, but also the facilities which are specifically meant for borderland people in India proper. For instance, I got the opportunity to visit the Duff Hostel in Kolkata, where most north eastern students stay whilst doing their undergraduate course at the Scottish Church College in Kolkata. The hostel, which is primarily meant for male students lacks proper lighting and toilets, and it seemed that the rooms had not been refurbished for years ${ }^{18}$. Students had not been provided with proper fans, lights or basic necessities. Living conditions in the hostel were very bad. It is very common to hear from students of north eastern descent that the Indian government does not look into these hostel facilities because they are the Indian 'other', and not like mainstream Indians. They look different to mainstream Indians, speak a different language and often dress differently. Many feel that had they been of Bengali, Punjabi, Marathi, descent then they would have been treated better and hostel facilities would have improved.

Most of my interviewees also mentioned that corruption levels were also very high, which needs to be looked into. Streamlining of bureaucracies would help in this connection. With regard to governance, there needs to be more transparency and accountability.

From a social standpoint, these borderland people who are often seen as the Indian 'other' by mainstream Indians, need to feel embraced by people living in India proper. Part of the problem is alienation and marginalisation and since these parts of India are geographically cut off from mainstream Indian society, people from these regions feel isolated. Communication links between India proper and the northeast most certainly need to be improved. Better communication between the two sides will go a long way in improving relations. Even when they come to India proper, many of them are subjected to racial discrimination due to their ethnic and cultural differences. Social inclusion is most certainly the way forward. For them to feel Indian and to reduce separatist tendencies, their voices will need to be heard in the central and regional decision making processes, particularly if the decision concerns their own region. The north east is subjected to the Armed Forces Special Powers Act, which is very much a part of the problem. Over the years, Indian security forces have often misused and abused this act and have caused absolute mayhem in the region. Rape has been a regular occurrence often committed by the armed forces on local north eastern women. Demilitarisation would help to some extent since it is the presence of the Indian Army and other para military forces which has paved the way for police brutality and all sorts of human rights abuses to take place, which has only added more fuel to the conflict. Although one of my interviewee's mentioned that the presence of security forces is required to deal with the underground elements, there needs to be more accountability and checks on what the Indian police and armed forces can and cannot do. Identifying insurgents will of course prove to be a major challenge, but once identified, it would be important to bring the disgruntled groups to the negotiating table. The conflicting views from different groups would need to be heard, and paid attention to. Also, there needs to be better communication between the different sides. After considering all of the above, hopefully something positive will begin to emerge.

${ }^{18}$ Participant observation, 2012, 2013, 2014 and 2015. 


\section{REFERENCES:}

Bajpai, K., 2002, Roots of Terrorism, New Delhi: Penguin Books.

Baruah, S., 2009, 'Separatist Militants and Contentious Politics in Assam, India: The Limits of Counter Insurgency', Asian Survey, 49(6), pp951-974.

Chandra, S., 2007, 'Understanding the Problem of Northeast India', India Review, 6(1), pp46-56.

Cline, L. E., 2006, 'The Insurgency Environment in Northeast India', Small Wars and Insurgencies, 17(2), pp126-147.

Dholabhai, N, 2014, 'Search in Myanmar after Jalpaiguri Blast and Malda Bus Attack: Cross Border Hunt for KLO', Calcutta: The Telegraph.

Dutt, S., 2000, 'Security of India's North-east: External Linkages', Strategic Analysis, 24(8),pp14951516.

Dutt, S., 2001, 'What Ails the Northeast: An Enquiry into the Economic Factors', Strategic Analysis, 25(1), pp73-87.

Dutt, S., 2000, 'Northeast Turmoil: Vital Determinants', Strategic Analysis, 23(12), pp2123-2133.

Farelly, N., 2009, 'AK47 /M16 Rifle-Rs15, 000 Each: What Price Peace on the Indo Burmese Border?', Contemporary South Asia, 17(3) pp283-297.

Ghose, S., 1998, Sanjoy's Assam, New Delhi: Penguin Books.

Glancey, J., 2011, Nagaland: A Journey to India's Forgotten Frontier, London: Faber and Faber.

Goswami, N., 'The Naga Intra Community Dialogue: Preventing and Managing Violent Ethnic Conflict', Global Change, Peace and Security, 22(1),pp93-120.

Haksar, N, 2013, Across the Chicken's Neck: Travels in North East India, New Delhi: Rupa.

Haokip, T., 2012, 'Recent Trends in Regional Integration and the Indian Experience', International Area Studies Review, 15(4), pp377-392.

Haokip, T., 2012, 'Political Integration of North East India: A Historical Analysis', Strategic Analysis, 36(2), pp 304-314.

Haokip, T., 2013, 'The Kuki-Naga Conflict in the Light of Recent Publications', South Asia Research, 33(1) pp77-87.

Hazarika, S., 2000, Rites of Passage: Border Crossings, Imagined Homelands, India's East and Bangladesh, New Delhi: Penguin Books.

Hazarika, S., 2011, Strangers of the Mist: Tales of War and Peace from India's Northeast, New Delhi: Penguin Books.

Hazarika, S., 2008, Writing on the Wall: Reflections of the Northeast, New Delhi: Penguin Books. 
Hussain, W., 2007, 'Ethno nationalism and the Politics of Terror in India's North east', South Asia: Journal of South Asian Studies, 30(1), pp93-110.

Joshi, V., 2007, 'The Birth of Christian Enthusiasm among the Angami of Nagaland', South Asia: Journal of South Asian Studies, 30(3), pp541-557.

Kikon, D., 2009, 'The Predicament of Justice: Fifty Years of the Armed Forces Special Powers Act in India', Contemporary South Asia, 17(3), pp271-282.

Kipgen, N., 2013, 'Politics of Ethnic Conflict in Manipur', South Asia Research, 33(1), pp21-38.

Mall, J., 2012, 'Naga terrorists in League with Politicians', in R.Sinha, ed, Secular India: Politics of Minorityism, New Delhi: Vitasta Publishing.

Mc-Duie-Ra, D., 2009, 'Vision 2020 or Revision 1958: the Contradictory Politics of Counter Insurgency in India's Regional Engagement', Contemporary South Asia, 17(3), pp313-330.

Mc-Duie-Ra, D., 2009, 'Fifty Year Disturbance: the Armed Forces Special Powers Act and Exceptionalism in a South Asian Periphery', Contemporary South Asia, 17(3), pp255-270.

McDuie-Ra, D., 2015, 'Is India Racist?': Murder, Migration and Mary Kom', South Asia: Journal of South Asian Studies, 38(2), pp304-319.

McDuie-Ra, D., 2016, 'Adjacent identities in Northeast India', Asian Ethnicity, 17(3), pp400-413.

Myint-U, T., 2011, Where China Meets India: Burma and the New Crossroads of Asia, London: Faber and Faber.

Nanavatty, R.K., 2013, Internal Armed Conflict in India: Forging a Joint Civil Military Approach, Centre for Land Warfare Studies, New Delhi: Pentagon Press.

Prasad, R.S., and Sinha, P.K., 2012, Tribal Movements and Politics in India, New Delhi: Anmol Publications.

Rammohan, E. N., 2014, 'Corruption and Insurgency in the North-East', in Subramanian, K.S., ed, Security, Governance and Democratic Rights: Essays on the North-East, New Delhi: Niyogi Books.

Rao, K.S., 2009, 'Insurgency in the North East: Ills and Remedies', Strategic Analysis, 33(2), pp208213.

Sabhlok, S.G., 2009, 'Civil Society and Development: Between Peace and Insurgency in the Northeast', South Asia: Journal of South Asian Studies, 32(3), pp501-517.

Singh, G., 2007, 'A Decade of Ceasefire in Nagaland', Strategic Analysis, 31(5), pp815-832.

Singh, G., 2008, 'In Search of Peace in Manipur: Lessons from Nagaland', Strategic Analysis, 32(6), pp1115-1129.

Singh, P., 2001, Kohima to Kashmir: On the Terrorist Trail, New Delhi: Rupa. 
Singh, M.A., 2008, 'Ethnic Diversity, Autonomy and Territoriality in Northeast India: A Case Study of Tribal Autonomy in Assam', Strategic Analysis, 32(6), pp1101-1114.

Sonwalkar, P., 2004, 'Mediating otherness: India's English language press and the Northeast', Contemporary South Asia, 13(4), 389-402.

Thong, T., 2010, 'Thy Kingdom Come: The Impact of Colonisation and Proselytisation on Religion among the Nagas', Journal of Asian and African Studies, 45(6), pp595-609.

The Telegraph, Calcutta/Kolkata, India, sixth January, 2014.

Vandenhelsken, M., and Karlsson, B.G., 2016, 'Fluid Attachments in Northeast India: Introduction', Asian Ethnicity, 17(3), pp330-339.

Webb, M.J., 2012, 'Escaping History or Merely Rewriting it? The Significance of Kashmir's Accession to its Political Future', Contemporary South Asia, 20(4), pp471-485.

Wolff, S., 2003, Disputed Territories, New York and Oxford: Berghahn Books.

Wouters, J.J.P., and Subba, T.B., 2013, 'The Indian Face, India's Northeast and The Idea of India', Asian Anthropology, 12(2), pp126-140. 